\title{
THE EXPERIENCES WITH REENGINEERING USING COMPUTER SIMULATION
}

\author{
MANLIG, F.; LADA, O. \& KoBlASA, F.
}

Abstract: This article focuses on the usage of the computer aided discrete event simulation. It tries to discuss situation, when on one side, this method is used more and more, and on the other side number of companies still underestimate it and are not much using it. The reason is insufficient level of knowledge required for its effective use, in spite of "massive campaign" of the computer simulation. The article reacts to this situation by presenting simulation approach, which focuses on the optimizing the assembly line in automotive industry.

Key words: simulation, assembly line, automotive industry
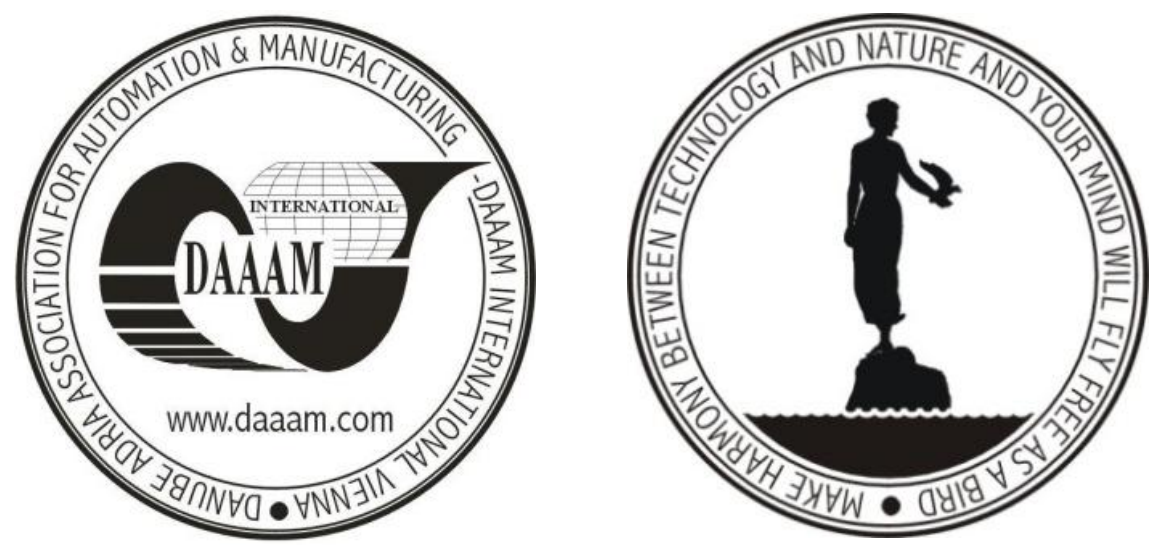

Authors' data: Assoc. Prof. Dr.-Ing. Manlig, F[rantisek]; Dipl.-Ing. Lada, O[ndrej]; Dipl.-Ing. Koblasa, F[rantisek], Technical University of Technology, Studentska 2, 461 17, Liberec, Czech Republic, frantisek.manlig@tul.cz, ondrej.lada@tul.cz, frantisek.koblasa@tul.cz

This Publication has to be referred as: Manlig, F[rantisek]; Lada, O[ndrej]; Koblasa, F[rantisek] (2011). The Experiences With Reengineering Using Computer Simulation, Chapter 45 in DAAAM International Scientific Book 2011, pp. 555-562, B. Katalinic (Ed.), Published by DAAAM International, ISBN 978-3-901509-84-1, ISSN 1726-9687, Vienna, Austria

DOI: 10.2507/daaam.scibook.2011.45 


\section{Introduction}

Although, it is frequently spoken about the necessity of the procedural and complex way for solving company's problems, numbers of companies, even from automotive, are using only the traditional analytical or graphical methods to solve them. Computer aided discrete event simulation (furthermore simulation) is still underestimated. Nowadays, this approach is shortsighted and may lead to high expenses of the given process management and control.

The managers of companies, which are not using simulation, are mentioning high price of the simulation software and uncertainty of simulation study economic return. These arguments cannot stand well. There are number of simulation softwares with various prices (in the Czech Republic e.g. - Showflow, Simu8, ProModel, Witness, Plant Simulation, Quest) and customer may choose completely by his own needs. It is also possible to compare number of simulation studies published in specialized papers, eventually to exploit study offered by some dealers, for the given simulation case problem.

It shows that the continuing problem, which is preventing the wider usage of computer simulation in manufacturing companies, is constant low level of knowledge, which is necessary for efficient usage, not meaning theoretical knowledge from the field of discrete simulation (which by the way, hardly any user can exploit). There is, more likely, lack of the awareness of the possible applications, its benefits (quantitative and also qualitative) and of the correct simulation study approach (It is not enough to be able to program model "only").

We are briefly dealing with this problem in the next chapter - i.e. Why and How to simulate.

\section{The use of computer simulation}

Why to simulate? The reasons for usage of the simulation are shown on two simple examples.

It is generally declared, that it is possible to solve processes entirely by the simulation, with regards to bottlenecks. What to imagine about it is demonstrated on the simple example, which presents the shifting bottleneck problem. There is the process model with one assembly workstation (Fig. 1). What will happen after adding one more assembly workstation? Even experienced managers will answer "Yes" on the question: "Will be the production doubled by adding one more assembly workstation". However, the opposite is true.

Another important aspect is that the simulation is able to take in to account influence of the dynamic stochastic events. The difference between deterministic and stochastic simulation approach is shown on two models where the second one take in to account variation of the performance of each worker (see Fig. 2).

From shown examples it can be seen that computer simulation thanks to its abilities to simulate behavior of the dynamic and stochastic processes within simulation model (so to predict it) appears as a tool, which can handle requirements on the best quality processes. 


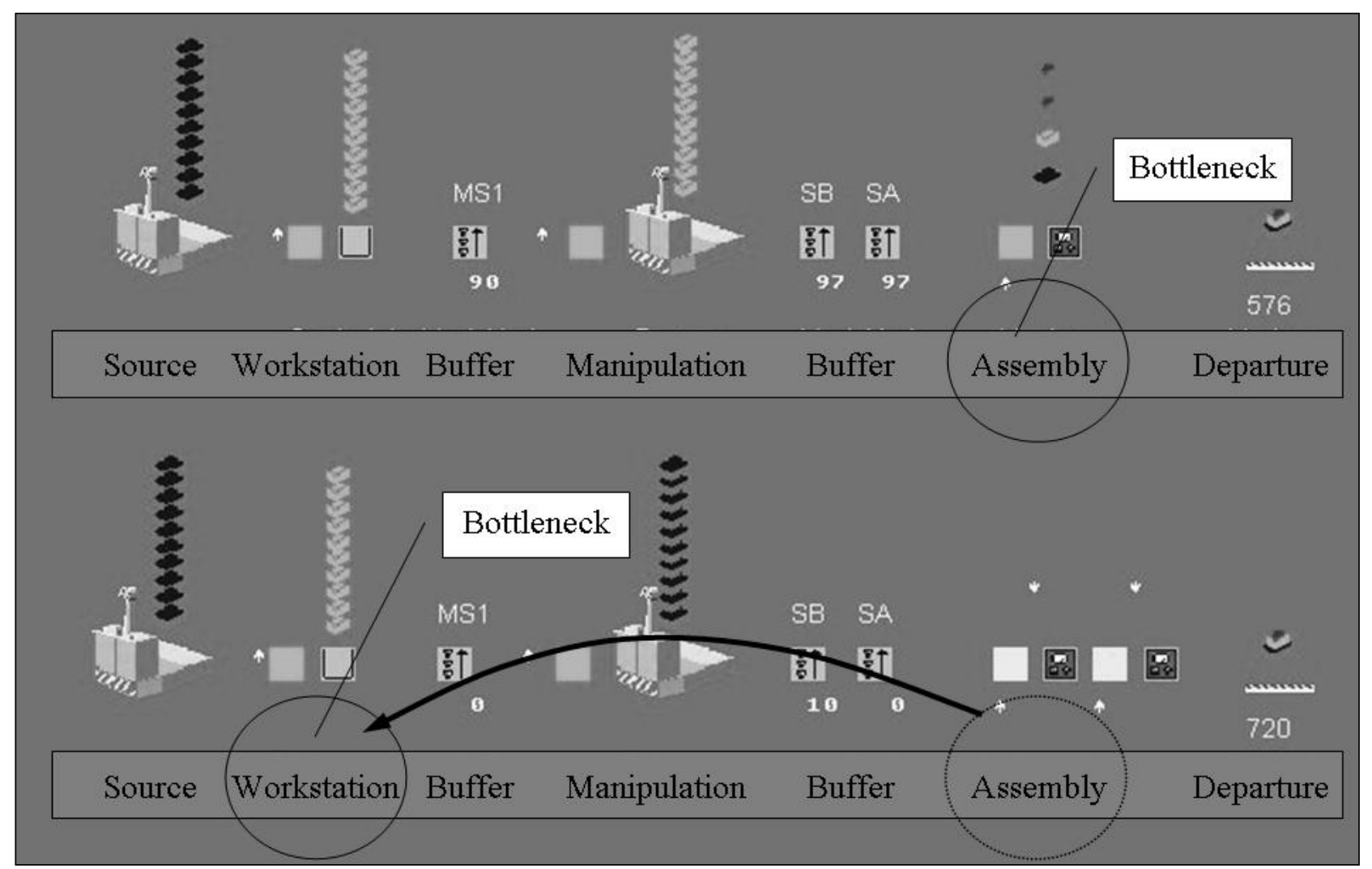

Fig. 1. Demonstration of the simple example - shifting bottleneck problem

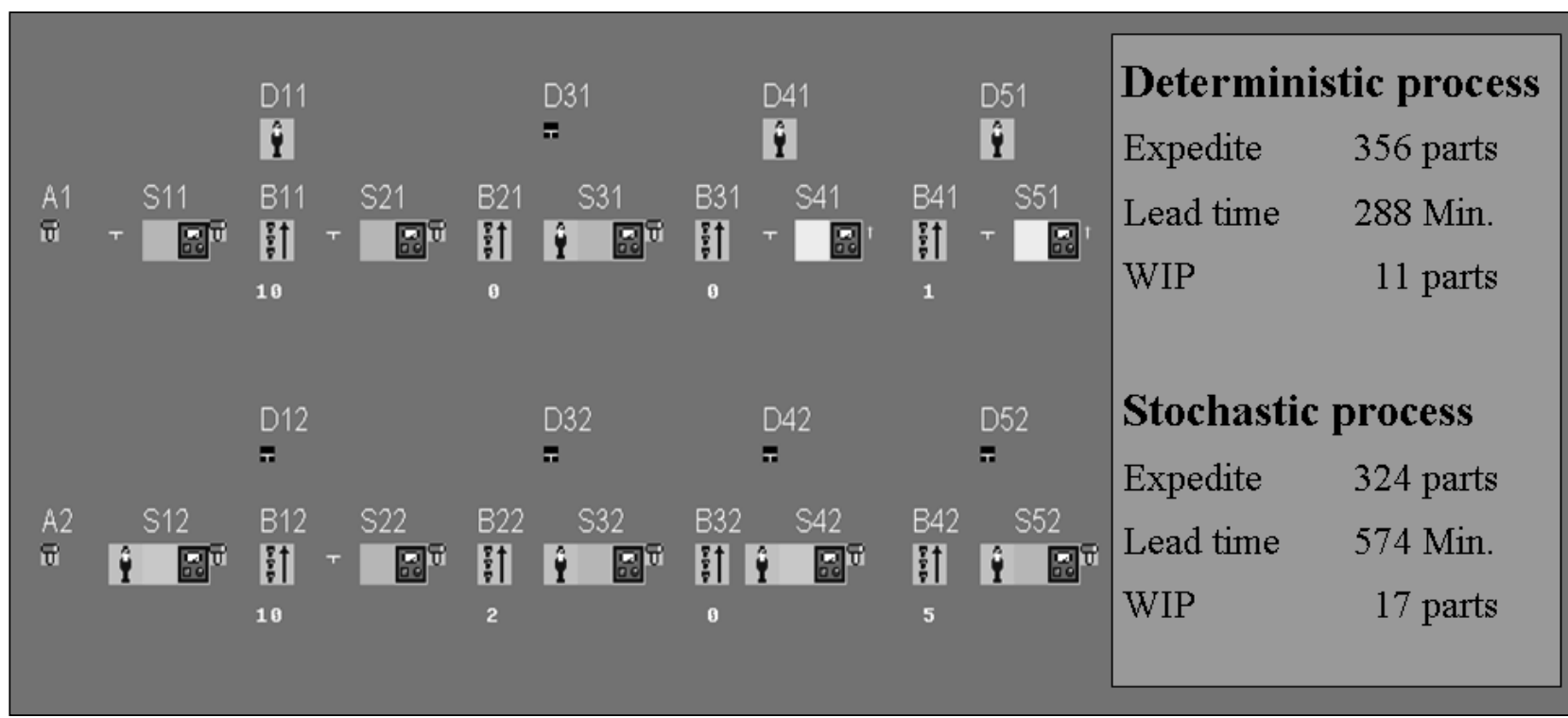

Fig. 2. Randomness and dependence of the manufacturing operations - example

The simulation should be used when the benefits exceeds its costs. This decision is often very difficult. The benefits and costs are very different from case to case and they are very hard to predict exactly in advance, because they depend on the current project. The Costs of the simulations are also depending on, if it is pilot or "repeated" project.

From the number of results of the case studies, made by authors of this article or articles in the specialized papers (e.g. Debnár et al., 1998; Kretschmar \& Manlig, 2008; Kuncová et. al., 2010; Kunzová et. al., 2011; Ulrych, 2008; VDI, 1993) it is possible to assume that with early and correct use of the simulation it is possible to 
reach quantitative benefits (e.g. worker or supply reduction), which are several times higher that its costs. Qualitative factors (e.g. simulation of the functionality and reliability of the process, prevention of the bad decision, gained knowledge, better arguments for the expert discussion), can lead to significant improvements of the operating results and competitive strength.

Let's remind the general approach of making the simulation project on the end of this chapter.

Every project has to start with the detail problem analysis and with selection of the proper method and the problem-solution approach. It is necessary to thing about at which phase to use simulation or if simpler method would be more suitable. This decision greatly influences the financial cost and the time of the project. Inappropriately selected solving method can lead to unnecessary extension and raise the price of the whole project. Computer simulation is not "ultimate answer" and it is not always suitable method on one side. But it is often appropriate to check results given by "other" methods to check influences of dynamic and stochastic effects or "try and compare" other possibilities on the other side.

Simulation project can be summarized into 4 phases.

The first phase is to define simulation project as set up of the implementation team, setting the goal and range of the project. This phase is usually underestimated and passed off. However, it is necessary to specify goals between submitter and solver. It precedes further misunderstandings and time delays within the necessary changes during the project. Beside it, by appropriate selection of the project's solving strategy we can significantly shorten following phases (model making phase and own experimenting) and so whole time of the project.

Following phase is to gather input data, to define elements of the system including its bindings, gathering dates and analysis for the stochastic of the random values and own model making. The main focus should be placed at the gathering and processing data and verification and validation of the model.

Next part of the simulation study is experimenting, which consist of systematic change of the parameter values of model to reach the defined goals. So experimenting is not trying - in the experimenting phase it is necessary also to handle a dilemma of wide number of the possible variation of solutions.

The simulation project is finished by assembling the documentation (i.e. keeping the knowledge), by evaluation of the results and realization of the "optimal solution".

Nowadays the market environment changes also its approach to the simulation software exploitation. Whereas earlier user was mainly the programmer, which "well or wrong" programmed given task, nowadays, he is at first the analyst, whom the use of the simulation results helps to find the optimal manufacturing strategy (Fig. 3). It is necessary to keep in mind that effective usage of simulation consists mainly in the thoroughly kept principles of the team work and the project management, including management of the previously given goals during each of the project phases. 
Before The main work is to make the model and "try it out"

The user is more likely programmer, which „makes" given task

The computer simulation is mainly used for large scale dynamic problems

Today The main work is to analyze the problem and to set the solution strategy.

The user is more likely analyst which uses simulation to find "optima“ manufacturing strategy.

The simulation becomes tool of the daily purpose.

Fig. 3. The change in the field of modern object oriented simulation systems usage

\section{Case study}

The computer simulation has been used for several years at the Department of the Manufacturing Systems at Technical University of Liberec. It finds applications in education, science and research and it is used also to optimize processes with industry cooperation. It is used to design manufacturing, to optimize production (e.g. Kretschmar \& Manlig, 2008) and also for the manufacturing scheduling (e.g. Koblasa \& Manlig, 2009).

There will be briefly presented a project of optimizing the assembly line in automotive industry.

\subsection{The problem definition}

Problem was solved within master thesis and deals with optimization of preassembling line of engine and gearbox for the car manufacturer.

The goal of the project was to find optimal placement of new operation assembly of the axle model with engine \& gear-box for SKD (,Semi-Knocked Down"). There are possible only two operation placement alternatives according to the assembly technology process, physical possibilities of the pre-assembly line and the customer's concept. Planed production increase was solved by adding assembly operation on the assembly line.

The frontiers of the simulation model are given by first tact of engine and gearbox preassembling to the last tact of assembling engine and gearbox with carriage to body shell. 


\subsection{Model making}

The emphasis was placed on data mining during project management. The data were collected from the information system and by own observation of the service workers. The logic of the assembly line system was gained by observing machinery in the real work conditions.

The base stone of the model is the element "track" and "vehicle", which creates three independent conveyors connected with the transfer places (see Fig. 4) and the elements of "Machine" type which are used as tool to generate delays.

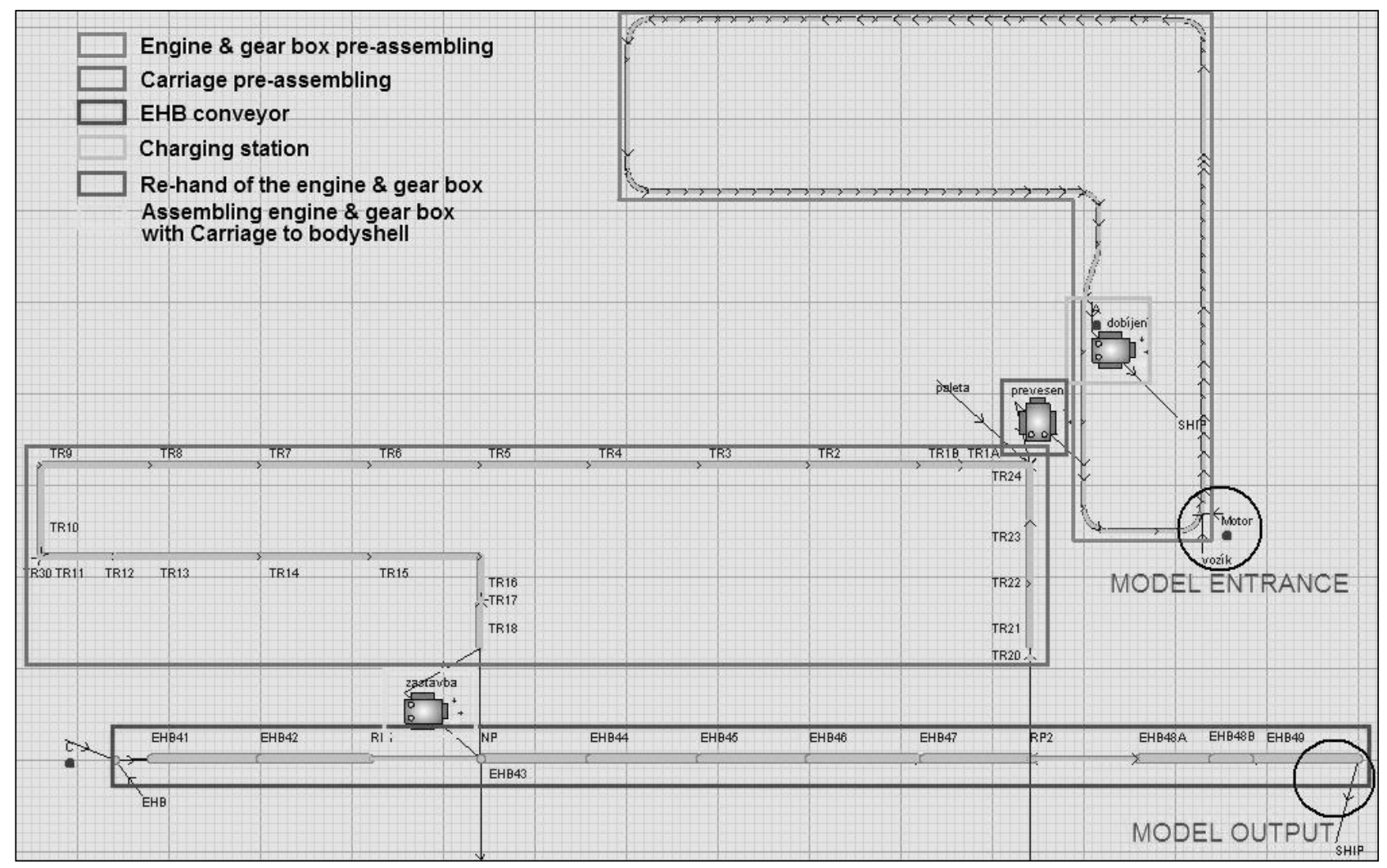

Fig. 4. The simulation model sample

The main aspects of the logic control are briefly described in the following points:

- Logic of the preassembling of the engine \& gear-box at AGV cart (Automated Guided Vehicle),

- Logic of the Charging station for AGV cart,

- Logic of the crossings at the carriage assembly,

- Logic of the carriage assembly in to car body,

- Delay generating system at the engine \& gear-box preassembling.

The crucial step to generate model according the submitter needs was to generate delays at engine \& gear-box preassembling. The main problem during modeling breaks was that it was not possible to set delays on the element "vehicle". Therefore was used the element "machine", which is generating delays for given tact of the manufacturing line (see Fig. 5). 


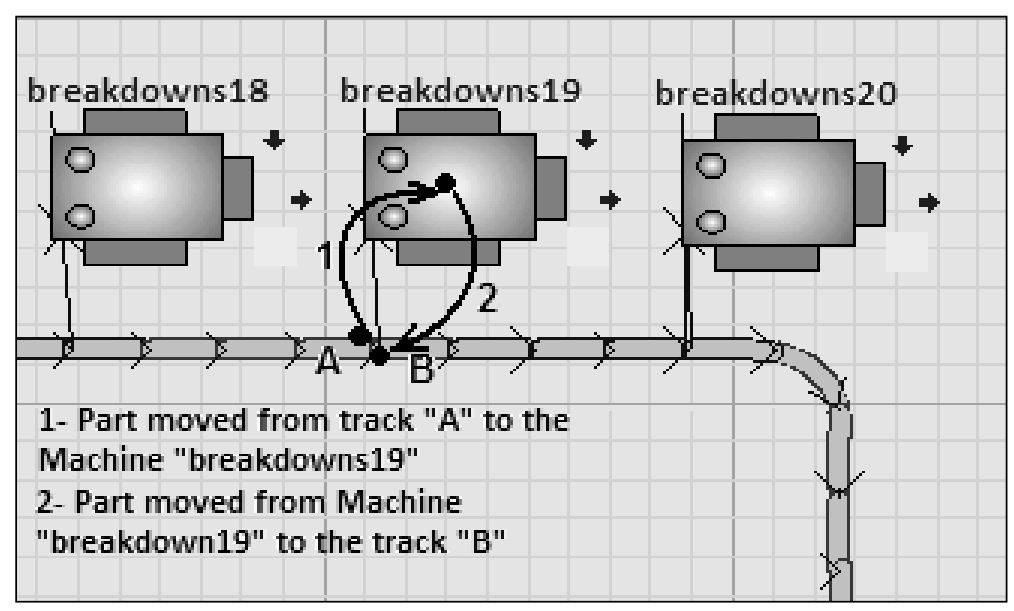

Fig. 5. Sample of delay generation at engine $\&$ gear-box preassembling

\subsection{The experimenting}

On the submitter demand there were made following experiments on the model of the current state. These experiments were used to verify setting of the manufacturing line:

- Experiment of the mean time to repair (MTTR) influence verification on throughput (i.e. verification of the suitable capacity for the buffer stocks).

- Experiment on the setting the suitable number of carts AGV - influence of delays and cross blockage on the system fluency.

The following experiments were made to verify influence of the technical changes on throughput of mentioned alternatives. The variables setting in both alternative models were similar with parameters during validation.

The experiments approved that the designed alternative " $A$ " has higher system throughput. The results of the experiments were compared with throughput of the present state (see Table 1.)

\begin{tabular}{|l|c|c|c|}
\hline & Basic model & Alternative "A“ & Alternative "B" \\
\hline Throughput [cars/day] in \% & 100,0 & 98,5 & 97,1 \\
\hline
\end{tabular}

Tab. 1. Throughput results of the alternatives.

\subsection{Finishing the project}

The simulation project was finished by making up the final report, completion of documentation and presentation of gained results to the submitter (to see more Lada 2009).

\section{Conclusion}

Nowadays it is required to take in to account complexity a dynamics of the company's processes and also possibility to take in account several solution variants. It means to change historical approach to solve the problems in manufacturing systems. It is not possible to make efficient processes only by "local" optimization of 
each parameter or sub processes, but it is necessary to look for the general optimum for the whole system.

Presented simulation study confirmed, that the computer simulation becomes the necessary supportive tool in the field of the designing new processes and for reengineering the present manufacturing systems. This is caused mainly by its ability to simulate each process property and so to make complex multi criteria analysis.

The authors' experiences also show, that the problem solved by the computer simulation cannot be underestimated and limited to "only" model making. The effective use of all its abilities and modern simulation software properties lies mainly in thoroughly made whole simulation project and in the teamwork of all involved specialists.

\section{Acknowledgements}

The research was realized using the support for special university investigations funded by the student grant competition of TUL (internal project No. 2821)

\section{References}

Debnár, R.; Košturiak, J. \& Kuric, I. (1998). Simulácia jako nástroj pre zvyšovanie produktivity a zisku v podniku. WEB časopis „Počitačom podporované systémy vstrojárstve“. ISSN 1335-3926. Available from: http://fstroj.utc.sk/journal/sk/024/024.htm Accessed: 1998-06-01

Koblasa, F., Manlig, F. (2009): Job shop scheduling problems with multi-shift work system. ACC Journal. Vol. XV, 2009 pp. 15-23 ISSN 1803-9782

Kretschmar, G., Manlig, F. (2008). Rechnersimulation - ein Werkzeug zur Produktionsoptimierung. Proceedings of international conference 1. Zittauer Maschinen-baukolloquium 2008. Wissenschaftliche Berichte, H. 101/2008, Hampel, R. (Hrsg.), pp. 59-63, Zittau, September 2008, HS Zittau/Görlitz

Kuncová, M.; Medonos, M.; Dlouhý, M. (2010). Využití simulačních modelů $\mathrm{k}$ analýze výrobního procesu. Proceedings of international conference 2010 Manufacturing systems today and tomorrow. Manlig, F. \& kol. (Ed.), ISBN 978-80-7372-669-0, Liberec, November 2010, TUL - KVS

Kunzová, B.; Roháč, J.; Volf, L. (2011): Využití simulačních metod ve výrobních procesech a systémech. Proceedings of conference Modelování, simulace a optimalizace podnikových procesư v praxi, Tuček, D. \& kol. (Ed.), pp. 369373, ISBN 978-80-260-0023-5, Zlín, March 2011, ČSOP, Praha

Lada, O. (2009). Ověrení plánovaného konceptu navýšení výrobních kapacit s podporou diskrétní simulace, TU of Liberec/KVS, Liberec [Master thesis]

Ulrych, Z. (2008). Simulační model pro analýzu výrobních procesů malosériové složité výroby. Proceedings of international conference Výrobní systémy dnes $a$ zítra 2008. Manlig, F. \& kol. (Ed.), ISBN 978-80-7372-416-0, Liberec, November 2008, TUL - KVS

VDI-Gesellschaft Fördertechnik Materialfluß Logistik (Hrsg.) (1993). Simulation von Logistik-, Materialfluß- und Produktionssystemen. Grundlagen. VDIRichtlinien 3633, Blatt 1. VDI-Verlag GmbH, Düsseldorf 